\title{
Study of agricultural impacts through fish base variables in different rivers
}

\author{
${ }^{1 * B .}$ R. Jha; ${ }^{2}$ H. Waidbacher; ${ }^{1}$ S. Sharma; ${ }^{2}$ M. Straif \\ ${ }^{1}$ Kathmandu University, Dhulikhel, P. O. Box 6250, Kathmandu, Nepal \\ ${ }^{2}$ Universität für Bodenkultur, Max Emanuel-Straße 17 A-1190 Wien, Austria
}

Received 14 December 2009; $\quad$ revised 8 February 2010; accepted 2 May 2010; availaECHonline 1 June 2010

\begin{abstract}
Dominant agricultural society of Nepal demonstrates the sign of compromises on its rural and virgin landscape. The current study investigates the fish base indices on some of its watershed. It is a proven fact that fish base variables such as species diversity and the abundance indicate the extent of impact by various disturbances on the ecological integrity of the river system. Three rivers, namely Jhikhukhola, Rapti and Tinau were studied to see the agricultural impact by taking fish species number and their abundance as the indicators in this work. The study was done for an academic purpose from 2003 to 2006 in which sampling was done using electro-fishing gear by standard wading method. Four replicates of sample taken in four major seasons were obtained in the field. Altogether, 10542 fishes of 24 genera and 34 species were captured during the entire sampling. The comparison of their distribution and abundance showed a clear sign of impact mainly on the downstream of the rivers indicating the rapid increase in unaccounted and indiscriminate use of agricultural inputs such as synthetic fertilizers and pesticides. This was further verified by nonparametric Kruskal-Wallis test which showed the significant variations in the impact on the downstream in major agricultural season.
\end{abstract}

Keywords: Agriculture; Ecological integrity; Electro-fishing; Impact; Pesticides

\section{INTRODUCTION}

The term 'ecological integrity' is very widely used in environmental debate, discourse, seminars, plans and literature but is very difficult to define in a single universal sense. Integrity normally implies a condition, which is unimpaired or a state of being complete or undivided (Karr and Chu, 1995; Noss, 1995; Westra, 1995; Karr, 2000). Nepal, because of its difficult terrain, rural set-up and virtually nonexistent industrialization appears very close to the above conditions and hence presumed to be pure and virgin land. However, this study shows the conditions are beginning to change.

The advantages of the use of fish as bioindicator have been mentioned by many authors (Okafor and Opuene, 2007; Vinodhini and Narayanan, 2008; Imam and El Bradei, 2009; Uriarte and Borja, 2009; Walters et al., 2009). Study of the of the agricultural disturbance on the integrity of the river system or simply the effects and impacts in the running water

*Corresponding Author Email: jhabibhuti@gmail.com Tel./Fax: +977 15008100 by taking fish as an indicator is widespread in the world, particularly in the developed countries. In fact, the first application of index of biotic integrity (IBI) was to assess the integrity of the river flowing through highly fertile agricultural land (Karr 1981; Suthar and Singh, 2008). Since then, a number of fish base studies on agricultural impacts have been done (Foy and Kirk, 1996; Lu et al., 2009; Penczak, 2009; Sanchez and Porcher, 2009).

McCarthy et al. (1997); Soto-Galera et al. (1998); Bohn and Kershner (2002); Balogh et al. (2003) and Moiseenko et al. (2008) have worked on the various aspects of agriculture and their effects on fish and its population. All these work highlights at least two things; first that the modern chemical intensive agricultural practice is affecting the nearby river channels and the second is that the fish diversity and its population are showing its impact. Agriculture is the most important and dominant economic activity in Nepal. It contributes to about $42 \%$ of the gross domestic product (GDP) and 
usually about one quarter of the country's development budget is allocated to this sector (MOPE, 2001). Though, the land use pattern of the country shows just $20.2 \%$ land under cultivation, over $80 \%$ of the total population still depends on agriculture for subsistence of living. Out of total agricultural GDP, livestock contributes $31 \%$ and is thus very significant. In addition to the production of milk and meat, it also provides animal power and manure to farmland for maintenance of soil fertility.

Some of the important disturbances to the rivers and streams from agriculture come from the landslides and soil erosion due to faulty agricultural practices on steep slopes, runoff of chemicals such as fertilizers and pesticides and introduction of new and exotic species. The main reason behind this is the mechanized chemical intensive so-called "modern agriculture" that encourages the blind and indiscriminate use of chemical fertilizers, pesticides and broad-spectrum antibiotics. It was in 1965/66, with the establishment of Agricultural Inputs Corporation (AIC), that organized supply of fertilizers, actually, began in the kingdom. The use of chemical fertilizers (NPK) per ha alone has increased tremendously from $7.6 \mathrm{~kg}$ in 1975 to $26.6 \mathrm{~kg}$ in 1998 (MOPE, 2001).

Pesticide use in Nepal has increased significantly in recent times due to the access to the market and the farmer's desire for high productivity. The national average consumption of pesticide is estimated to be $650 \mathrm{~g} / \mathrm{ha}$ (MOPE, 1998) in commercial farming, which is very high compare to the other countries in the region. According to the Directorate of Plant Protection (DOPP), the country imported $33356 \mathrm{~kg}$ of insecticides, $15577 \mathrm{~kg}$ of fungicides/bactericides, 6748 $\mathrm{kg}$ of herbicides and $400 \mathrm{~kg}$ of rodenticides in the year 1997.

The disturbance caused by the new intensive agricultural practice has proliferated into the rural areas and is now a serious threat to once pure and virgin water. This study aims to assess the impact of this practice by using fish base indices there by gathering the information regarding fisheries resources in one hand and the quality of the water on the other hand. Three case studies from rivers Jhikhukhola, East Rapti and Tinau of Nepal have been incorporated in this work that lasted around four years from 2003 to 2007 and also included one complete cycle of seasonal samplings. The main objectives of this work are to study the fish diversity in the selected rivers of Nepal, to study the abundance of fish species in those selected rivers and to study the impact of current agricultural practices on the selected rivers by taking fish diversity and its abundance as the indicators.

\section{MATERIALS AND METHODS}

The main strategy of this work is to compare the headwater of the selected rivers with that of the section of river coming out of the fertile valley or just before draining in the main channel in terms of fish base variables. Three rivers, namely Jhikhukhola, East Rapti and Tinau from central and western region of Nepal were selected for this purpose. Each river had two fixed sampling sites or stations called as upstream and downstream and the result is the comparison between two. Fish sampling was done using electro fishing device, which when applied in water shocks the fish in its range for a moment and could be captured easily by the net (Cowx and Lamarque, 1990). The method followed here was a simple but standard wading type with a person carrying a backpack electro-fishing unit. He was assisted by two persons each carrying a long dip net to collect the shocked fish and a third person carrying a bucket to empty the nets. In each site, the fish sampling was done in two runs, 1 and 2, respectively. The stretch of each sampling site was mostly between 50 to $100 \mathrm{~m}$ long. The time span for each run was taken separately and is an important factor to calculate the catch per unit effort (CPUE), which in turn is an important tool to see other population dynamics of the fish. The time for each run were tried to be fixed around 20 minutes and was never less than 30 min for the total of run 1 and 2 in any of the sample in all seasons. Consistent sampling design for each site in each season was applied to avoid biased results. The first set of field sampling of this study in selected river sections of Nepal began on the third week of February 2003 on the onset of spring season (February/March). After the first sampling, replicate of it were taken corresponding to all major seasons, summer or premonsoon (May/June), autumn or postmonsoon (October) and winter (December/January). Finally four sets of data representing each season, spring, 
summer/premonsoon, autumn/postmonsoon and winter were collected spanning until the beginning of 2004.

With 6 sites and four replicate of these, there are altogether 24 samplings that constitute this work. Many of the fish species were identified in the fieldwork itself with the help of number of keys (Day, 1878; Talwar and Jhingran, 1991; Shrestha, 1994) and the local people. Some unidentified species were preserved in $10 \%$ formalin and were latter identified with the generous help of the experts. The fish species identified in the sites were released after the observation, while those unidentified were preserved in the museum after identification. For the fish taxonomy, Shrestha (2001) was followed, as it is the latest for the fish species in this country. Data processing and analysis were done in Universität für Bodenkultur, Vienna.

\section{RESULTS AND DISCUSSION}

In total, 10,542 fishes of 24 genera and 34 species were captured during the entire sampling period that lasted for more than one complete year encompassing all seasons and including three fertile river valleys, Jhikhukhola, East Rapti and Tinau from central and western region of Nepal.

Altogether, 2227 fishes of 12 species were captured from Jhikhukhola with the good yearly average abundance of 79.17 (Table 1). However, comparison of their distribution in upstream and downstream highlights the increasing impact of agriculture. The number of species in upstream all round the year was 8 compared to 12 in the downstream (Table 2). Similarly, the yearly average abundance of fish in upstream was 46.28 while that in the downstream was more than double at 112.05. Likewise, in East Rapti 3627 fishes of 30 species were captured with a very healthy abundance of 121.44 (Table 1 ). In this case too a comparison of the distribution of fish in upstream and downstream showed a slight indication of the impact of agriculture. Here, the number of species in upstream all round the year was 19 compared to 25 in the downstream (Table 2). The yearly average abundance of fish in upstream was slightly high at 135.26 compared to 107.61 in the downstream. Tinau River was studied for multiple impacts and hence had a multiple of samplings. In total 8255 fishes of 29 species with healthy looking average abundance of 95.95 were recorded from this river. In the study of agricultural impact alone 4688 fishes of 21 species were recorded overall. In upstream the number of species was 16 with the average abundance of 246.8 while in the downstream it was 18 and 83.33 respectively. The high average abundance of fish in upstream was mainly due to the high abundance of single species called Puntius sophore. The seasonal variation of the fish base variables shows clearer picture of the impact of agricultural inputs (Figs. 1 and 2). Except for the spring, the season following the least activity in the

Table 1: Yearly details of the fish sample

\begin{tabular}{lccr}
\hline Rivers $\downarrow$ & No. of fish sampled & No. of species & Abundance \\
\hline Jhikhukhola & 2227 & 12 & 79.17 \\
East Rapti & 3627 & 30 & 121.44 \\
Tinau & 4688 & 21 & 95.95 \\
\hline
\end{tabular}

Table 2: Comparison of the fish base variables to see the impact

\begin{tabular}{|c|c|c|c|c|c|c|c|}
\hline \multirow{2}{*}{$\begin{array}{l}\text { Rivers } \rightarrow \\
\text { Seasons } \downarrow\end{array}$} & \multirow[b]{2}{*}{ Sites } & \multicolumn{2}{|c|}{ Jhikhukhola } & \multicolumn{2}{|c|}{ East Rapti } & \multicolumn{2}{|c|}{ Tinau } \\
\hline & & $\begin{array}{c}\text { Number } \\
\text { of species }\end{array}$ & Abundance & $\begin{array}{c}\text { Number } \\
\text { of species }\end{array}$ & Abundance & $\begin{array}{c}\text { Number of } \\
\text { species }\end{array}$ & Abundance \\
\hline \multirow{3}{*}{ Spring } & Upstream & 7 & 32 & 16 & 179.80 & 14 & 225.94 \\
\hline & Downstream & 7 & 134.33 & 15 & 187.17 & 16 & 198.25 \\
\hline & Upstream & 7 & 48.33 & 13 & 151.5 & 11 & 250.36 \\
\hline \multirow[t]{2}{*}{ Summer } & Downstream & 6 & 71.67 & 16 & 77.25 & 5 & 23.75 \\
\hline & Upstream & 6 & 45.5 & 13 & 71 & 12 & 310.39 \\
\hline \multirow[t]{2}{*}{ Autumn } & Downstream & 8 & 39.5 & 17 & 78.25 & 10 & 55.9 \\
\hline & Upstream & 7 & 59.28 & 13 & 138.75 & 14 & 200.5 \\
\hline \multirow[t]{2}{*}{ Winter } & Downstream & 7 & 202.72 & 10 & 87.78 & 11 & 55.43 \\
\hline & Upstream & 8 & 46.28 & 19 & 135.26 & 16 & 246.8 \\
\hline Total & Downstream & 12 & 112.05 & 25 & 107.61 & 18 & 83.33 \\
\hline
\end{tabular}


Fish base study of rivers

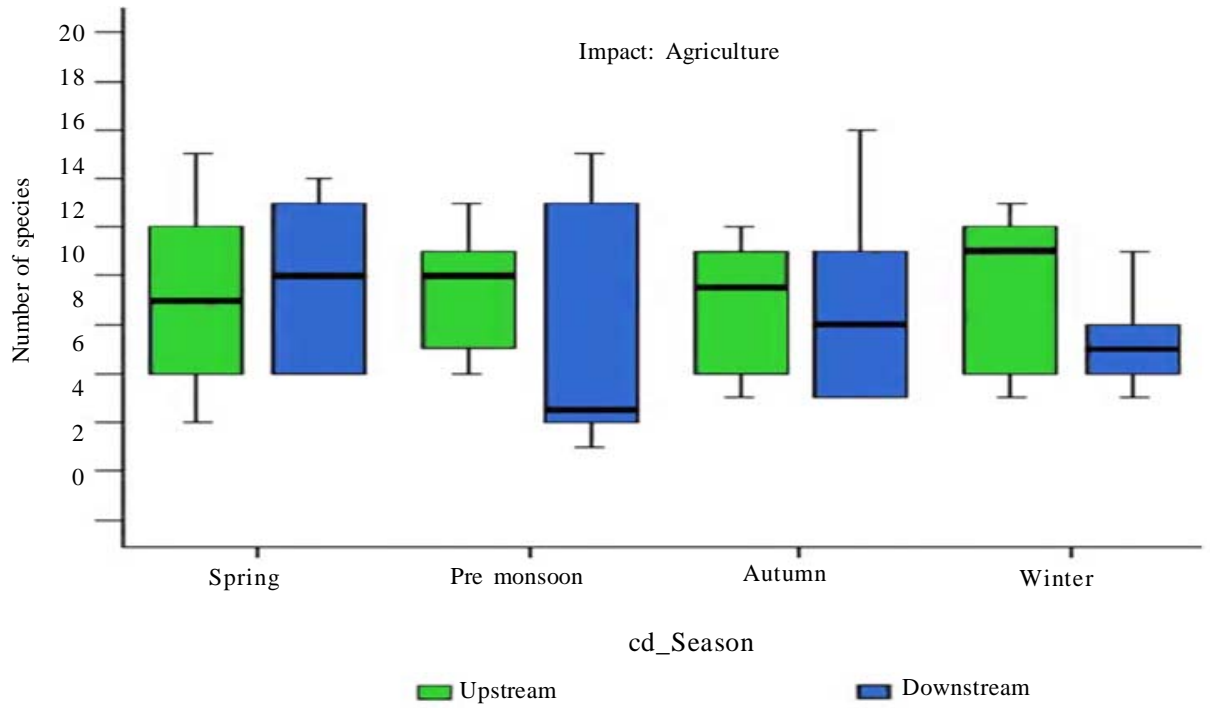

Fig. 1: Seasonal variation of number of species in agricultural impacts

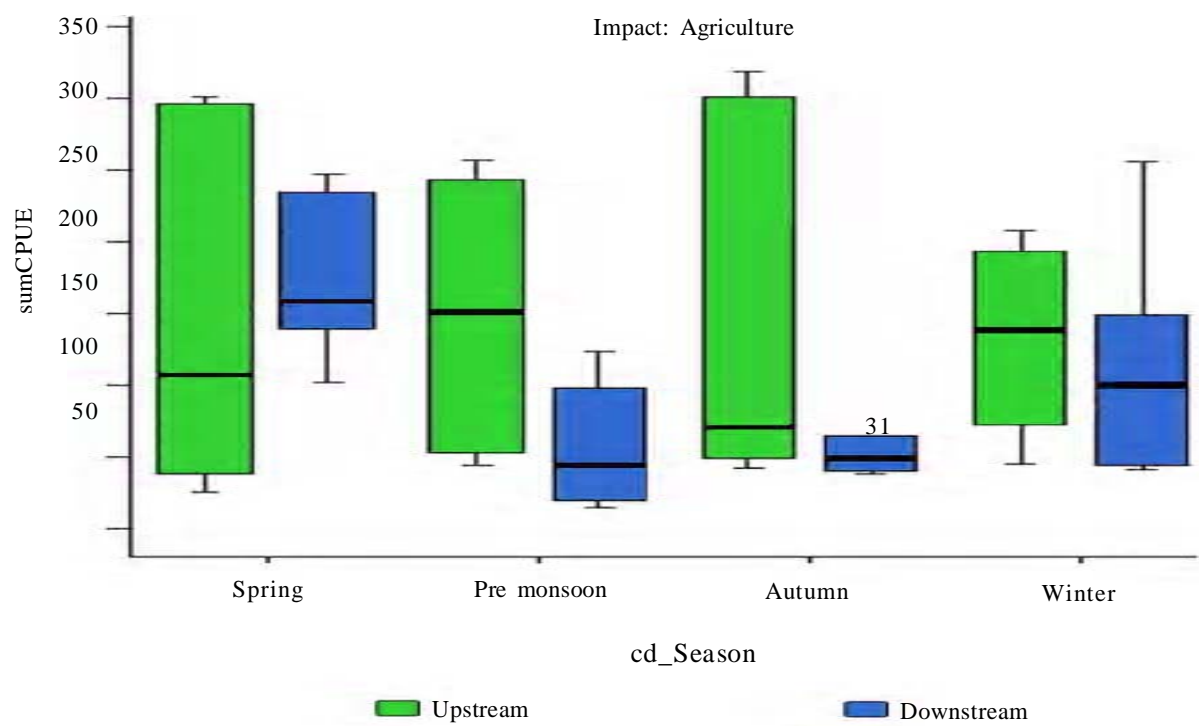

Fig. 2: Seasonal variation of the abundance of fish in agricultural impacts

agricultural field, the number of fish species and the average abundance are consistently lower in all seasons. The statistical analysis of the fish base variables produced the most conclusive result of the impact of agriculture. The nonparametric KruskalWallis test (Johnson, 2004) on the data of abundance for the seasonal variation of impacts showed the asymptotic significance as 0.984 in upstream and 0.010 in downstream. The result indicated that the seasonal fluctuation of the impact in the downstream, where ultimately the excess agricultural inputs find their way through run-off is statistically significant.

Nepal has emerged as no exception as the agriculture is a backbone of country's economy and utilizes large amount of fertilizers, pesticides and organic manures. Study of three different cases, Jhikhukhola in Kavre district, East Rapti in 
Makawanpur and Chitwan districts and Tinau in Palpa district showed some differences in the abundance of fish and total number of species but the differences were not decisive. The value of nonparametric Mann-Whitney test (Jha, 2006) for the impact of agriculture in terms of abundance of fish in all rivers also showed no significance $(\mathrm{P}>0.05)$. In the same way, parametric one-way ANOVA (Jha, 2006) for the impact of agriculture in terms of number of species too showed no significance $(\mathrm{P}>0.05)$. However, the nonparametric Kruskal-Wallis test in terms of abundance showed significant seasonal differences in downstream $(\mathrm{P}<0.05)$. This indicated that downstream site exhibits seasonal differences of the impacts of agriculture. The median value of abundance was highest in spring and lowest in premonsoon (Fig. 2) indicating that due to the lowest flow of water the concentration of the pollutants was highest and thus less abundance. This was further proved by the second variable, number of species, which was lowest in premonsoon in downstream. Nevertheless, the individual cases were found to be different. The statistically significant result of the agricultural impact were also obtained by Kammerbauer and Moncada (1998); Liang et al. (1999); Berg (2000); Okoumassoun et al. (2002); De Oliveira Filho et al. (2004) and Nouri et al., (2008)

The results indicated that the prevalent agricultural practices in the country have potential to change the integrity of the rivers as the chemical fertilizers and pesticides, ultimately, finds its way into the rivers. The adverse effects of these chemicals such as water pollution, bioaccumulation of the chemicals in fish tissues and the fluctuations of the natural fish stock have been well established (Fowlie et al., 2008; Oczkowski and Nixon, 2008; Dorea, 2008). Though the species richness and the abundance of fishes were more in disturbed sites due to the nutrient input, the integrity of the river, which might be defined as the natural state, was found to be degraded. This is a classical example where the high productivity does not always means the high integrity. The impact itself is not much alarming as it is in the initial stage but it is the state of the awareness of the people that is of more concern. With illiteracy and poverty engulfing the entire country particularly the rural, the effect of unnecessary input of chemicals in the field will only increase in the near future. In fact, it is an urge for immediate economic gain that the simple, humble and uneducated rural mass is forced to use overdose of the chemicals. This is a compulsion of the common people and it is helped by the government and the market for their own narrow benefit.

\section{CONCLUSION}

The present study aimed to see the impact of changing agricultural practice on the integrity of river channels on the remote and rural areas of Nepal by taking fish base variables has shown that the previously untouched and virgin landscape has been vastly tampered by the excessive application of synthetic agricultural inputs. There was a clear spatial and temporal variation in fish assemblage indicating the impacts of agriculture on the case studied. The impact, though mild, was also proved significant by nonparametric Kruskal-Wallis test (0.010: $\mathrm{P}<0.05)$.

\section{ACKNOWLEDGEMENTS}

It is acknowledged the support of Kathmandu University, Universität für Bodenkultur, Austrian Exchange Service (ÖAD) and IUCN, Nepal for this work. The authors also acknowledge the effort of the entire team during fieldwork of this study.

\section{REFERENCES}

Balogh, S. J.; Huang, Y.; Offerman, H. J.; Meyer, M. L.; Johnson, D. K., (2003). Methylmercury in rivers draining cultivated watersheds. Sci. Total Environ., 304 (1-3), 305313 (9 pages).

Berg, H., (2000). Pesticide use in rice and rice-fish farms in the Mekong Delta, Vietnam. Crop. Prot., 20 (10), 897905 (9 pages).

Bohn, B. A.; Kershner, J. L., (2002). Establishing aquatic restoration priorities using a watershed approach. J. Environ. Manage., 64 (4), 355-363 (9 pages).

Cowx, I. G.; Lamarque, P., (1990). Fishing with electricity, applications in freshwater fisheries management. Oxford. Fishing News Books, Blackwell Scientific Publications.

Day, F., (1878). Fishes of india being a natural history of the fishes known to inhabit the seas and freshwaters of India, Burma and Ceylon, Vols. I and II. Today and tomorrow book Agency, New Delhi.

De Oliveira Filho, E. C.; Lopes, R. M.; Paumgartten, F. J. R., (2004). Comparative study on the susceptibility of freshwater species to copper-based pesticides. Chemosphere, 56 (4), 369-374 (6 pages).

Dorea, J. G., (2008). Persistent, bioaccumulative and toxic substances in fish: Human health considerations. Sci. Total Environ., 400 (1-3), 93-114 (22 pages).

Fowlie, A. R.; Hodson, P. V. ; Hickey, M. B. C., (2008). 
Spatial and seasonal patterns of Mercury concentrations in fish from the St. Lawrence river at Cornwall, Ontario: Implications for monitoring. J. Great Lakes Res., 34 (1), $72-85$ (14 pages).

Foy, R. H.; Kirk, M., (1996). Agriculture and water quality: A regional study. Int. J. Multiphas. Flow, 22 (1), 124 (1 page).

Imam, E. H.; El Baradei, S. A., (2009). Impact of control structures on assimilative capacity of rivers and fish habitat. Int. J. Environ. Sci. Tech., 6 (2), 315-324 (10 pages).

Jha, R. B., (2006). Fish ecological studies and its application in assessing ecological integrity of rivers in Nepal. Ph.D. dissertation. Kathmandu University, Dhulikhel, Nepal.

Johnson, R. A., (2004). Miller and Freund's Probability and Statistics for Engineers. $6^{\text {th }}$ Ed., Pearson Education Inc. New Jersey 07458, USA.

Kammerbauer, J.; Moncada, J., (1998). Pesticide residue assessment in three selected agricultural production systems in the Choluteca river basin of Honduras. Environ. Pollut., 103 (2-3), 171-181 (11 pages).

Karr, J. R., (1981). Assessment of biotic integrity using fish communities. Fisheries, 6 (6), 21-27 (7 pages).

Karr, J. R., (2000). Health, integrity and biological assessment: The importance of measuring whole things, in: Pimentel, D., Westra, L.; Noss, R. F. (Eds.), Ecological integrity: Integrating environment conservation and health, Island Press, Washington DC.

Karr, J. R.; Chu, E. W., (1995). Ecological integrity: Reclaiming lost connections, in: Westra, L., Lemons, J. (Eds.), Perspectives on ecological integrity, Kluwer Academic Publishers, The Netherlands.

Liang, Y.; Cheung, R. Y. H.; Wong, M. H., (1999). Reclamation of wastewater for polyculture of freshwater fish: Bioaccumulation of trace metals in fish. Water Res., 33 (11), 2690-2700 (11 pages).

Lu, X. W.; Dang, Z.; Yang, C., (2009). Preliminary investigation of chloramphenicol in fish, water and sediment from freshwater aquaculture pond. Int. J. Environ. Sci. Tech., 6 (4), 597-604 (8 pages).

McCarthy, L. H.; Stephens, G. R.; Whittle, D. M.; Peddle, J.; Harbicht, S.; LaFontaine, C.; Gregor, D. J., (1997). Baseline studies in the Slave river, NWT, 1990-1994: Part II. Body burden contaminants in whole fish tissue and livers. Sci. Total Environ., 197 (1-3), 55-86 (32 pages).

Moiseenko, T. I.; Gashkina, N. A.; Sharova, Yu. N.; Kudryavtseva, L. P., (2008). Ecotoxicological assessment of water quality and ecosystem health: A case study of the Volga River. Ecotoxicol. Environ. Safe., 71 (3), 837850 (14 pages).

MOPE, (1998). State of the environment, Nepal (agriculture and forest). HMG/Ministry of population and environment, Kathmandu.

MOPE, (2001). State of the environment, Nepal (agriculture and forest). HMG/Ministry of population and environment, Kathmandu.
Noss, R. F., (1995). Ecological integrity and sustainability: Buzzword in conflict. Westra, L.; Lemons, J. (Eds.), Perspectives on ecological integrity, Kluwer Academic Publishers, The Netherlands.

Nouri, J.; Mahvi, A. H.; Jahed, G. R.; Babaei, A. A., (2008). Regional distribution pattern of groundwater heavy metals resulting from agricultural activities. Environ. Geol., 55 (6), 1337-1343 (7 pages).

Oczkowski, A.; Nixon, S., (2008). Increasing nutrient concentrations and the rise and fall of a coastal fishery. A review of data from the Nile Delta, Egypt. Estuar. Coast. Shelf Sci., 77 (3), 309-319 (11 pages).

Okafor, E. Ch., Opuene, K., (2007). Preliminary assessment of trace metals and polycyclic aromatic hydrocarbons in the sediments. Int. J. Environ. Sci. Tech., 4 (2), 233-240 (8 pages).

Okoumassoun, L. E.; Brochu, C.; Deblois, C.; Akponan, S.; Marion, M.; Averill-Bates, D.; Denizeau, F., (2002). Vitellogenin in tilapia male fishes exposed to organochlorine pesticides in Oueme River in Republic of Benin. Sci. Total Environ., 299 (1-3), 163-172 (10 pages).

Penczak, T., (2009). Fish assemblage compositions after implementation of the IndVal method on the Narew River system. Ecol. Model., 220 (3), 419-423 (5 pages).

Sanchez, W.; Porcher, J. M., (2009). Fish biomarkers for environmental monitoring within the water framework directive of the European Union. In-situ trialing and validation of ecological and chemical water measurements. TrAC. Trend. Anal. Chem., 28 (2), 150-158 (9 pages).

Shrestha, J., (1994). Fishes, fishing implements and methods of Nepal. Smt. M.D. Gupta, Lalitpur colony, Lashkar (Gwalior), India.

Shrestha, J., (2001). Taxonomic revision of fishes of Nepal. Jha, P. K.; Baral, S. R.; Karmacharya, S. B.; (Eds.), Environment and agriculture: Biodiversity, agriculture and pollution in South Asia, Ecological Society (ECOS), Kathmandu Nepal.

Soto-Galera, E.; Daz-Pardo, E.; Lopez-Lopez, E.; Lyons, J., (1998). Fish as indicators of environmental quality in the Rio Lerma Basin, Mexico. Aqua. Ecosys. Health Manage., 1 (3-4), 267-276 (10 pages).

Suthar, S.; Singh, S., (2008). Vermicomposting of domestic waste by using two epigeic earthworms (Perionyx excavatus and Perionyx sansibaricus). Int. J. Environ. Sci. Tech., 5 (1), 99-106 (8 pages).

Talwar, P. K.; Jhingran, A. G., (1991). Inland fishes of India and adjacent countries, Vol. 1 and 2. Oxford and $\mathrm{IBH}$ Publishing Company Pvt. Ltd., New Delhi.

Uriarte, A.; Borja, A., (2009). Assessing fish quality status in transitional waters, within the european water framework directive: Setting boundary classes and responding to anthropogenic pressures. Estuar. Coast. and Shelf Sci., 82 (2), 214-224 (11 pages).

Vinodhini, R.; Narayanan, M., (2008). Bioaccumulation of heavy metals in organs of fresh water fish Cyprinus carpio (Common carp). Int. J. Environ. Sci. Tech., 5 (2), 179182 (4 pages). 
Walters, D. M.; Roy, A. J.; Leigh, D. S., (2009). Environmental indicators of macroinvertebrate and fish assemblage integrity in urbanizing watersheds. Ecol. Indic., 9 (6), 1222-1233 (12 pages)
Westra, L., (1995). Ecosystem integrity and sustainability: The foundational value of the wild. Westra, L.; Lemons, J. (Eds.), Perspectives on ecological integrity, Kluwer Academic Publishers, The Netherlands.

\section{AUTHOR (S) BIOSKETCHES}

Jha, R. B., Ph.D., Assistant Professor, Department of Environmental Science and Engineering, Kathmandu University, Dhulikhel, Nepal. Email: jhabibhuti@gmail.com

Waidbacher, H., Ph.D., Full Professor, Universität für Bodenkultur, Max Emanuel-Straße 17 A-1190 Wien, Austria.

Email: herwig.waidbacher@boku.ac.at

Sharma, S., Ph.D., Full Professor, Department of Environmental Science and Engineering, Kathmandu University, Dhulikhel, Nepal. Email: subodh.sharma@ku.edu.np

Straif, M., B.Sc., Universität für Bodenkultur, Max Emanuel-Straße 17 A-1190 Wien, Austria.

Email: michael.straif@boku.ac.at

How to cite this article: (Harvard style)

Jha, R. B.; Waidbacher, H.; Sharma, S.; Straif, M., (2010). Study of agricultural impacts through fish base variables in different rivers. Int. J. Environ. Sci. Tech., 7 (3), 609-615. 